\title{
CHEMICAL PROPERTIES OF PELLETS OF Pinus sp. TORREFIED IN A SCREW TYPE REACTOR
}

\author{
Mateus Alves de Magalhães ${ }^{1 *}$, Angélica de Cássia Oliveira Carneiro ${ }^{1}$, Benedito Rocha Vital ${ }^{1}$, Carlos Miguel \\ Simões da Silva ${ }^{1}$, Emylle Veloso Santos Costa ${ }^{2}$, Paulo Fernando Trugilho ${ }^{2}$
1 *Federal University of Viçosa, Department of Forest Engineering, Viçosa, Minas Gerais, Brazil - mateusmagalhaes91@ gmail.com; cassiacarneiro1@gmail.com; benedito.vital@gmail.com; karmiguel@yahoo.com.br
${ }^{2}$ Federal University of Lavras, Department of Forest Sciences, Lavras, Minas Gerais, Brazil - emylleveloso@yahoo.com.br; \\ trugilho@dcf.ufla.br
}

Received for publication: 25/05/2017 - Accepted for publication: 07/05/2018

\begin{abstract}
The combination of pelletization and torrefaction allows for obtaining pellets with higher energetic density. Thus, biomass becomes more attractive and usable for energetic purposes, and therefore, knowing the chemical properties becomes important to guarantee the quality of the torrefied pellets for fuel. The objective of this study was to evaluate the effect of torrefaction of Pinus sp. pellets on their chemical properties. The wood was previously transformed into particles and dried to $16 \%$ moisture content for further pelleting. For the torrefaction, the pellets were dried to $0 \%$ moisture content and subjected to heat treatment in a screw type reactor at the temperatures of 210,250 , and $290{ }^{\circ} \mathrm{C}$ and the times of 10,20 , and 30 minutes. In order to determine the chemical properties, the structural chemical composition, immediate chemical composition, elemental composition, and thermogravimetric analysis were performed. The torrefaction promoted significant changes in the chemical properties of Pinus sp. pellets, especially regarding the proportional increase of carbon content in detriment to oxygen reduction, increase of the thermal stability, and proportional increase of the lignin content by the reduction of the hemicelluloses. This improves the energetic quality of the biomass and turns it into a more competitive fuel when compared to fossil fuels.

Keywords: Torrefaction, densification, energetics biomass.
\end{abstract}

\section{Resumo}

Propriedades químicas de pellets de Pinus sp. torrificados em reator tipo rosca sem fim. A combinação da peletização e torrefação permite obter pellets torrificados com maior densidade energética, tornando assim a biomassa mais atrativa e utilizável para fins energéticos. Sendo assim, torna-se importante o conhecimento de suas propriedades químicas a fim de garantir a qualidade dos pellets torrificados como combustível. O objetivo deste estudo foi avaliar o efeito da torrefação de pellets de Pinus sp. em suas propriedades químicas. A madeira foi previamente transformada em partículas e seca a $16 \%$ de umidade para posterior peletização. Para a torrefação, os pellets foram secos a $0 \%$ de umidade e submetidos a tratamento térmico em um reator tipo rosca sem fim, nas temperaturas de 210,250 e $290{ }^{\circ} \mathrm{C}$ e nos tempos de residência de 10,20 e 30 minutos. Para o conhecimento das propriedades químicas, foi determinada a composição química estrutural, composição química imediata, composição elementar e análise termogravimétrica. A torrefação promoveu alterações significativas nas propriedades químicas dos pellets de Pinus sp., destacando-se o aumento proporcional do conteúdo de carbono em detrimento da redução de oxigênio, aumento da estabilidade térmica e aumento proporcional do conteúdo de lignina pela redução, principalmente, das hemiceluloses, o que melhora a qualidade energética da biomassa e a torna mais competitiva frente aos combustíveis fosseis.

Palavras-chave: Torrefação, densificação, biomassa energética.

\section{INTRODUCTION}

Worldwide, petroleum derivatives dominate the energy market. However, these sources are not environmentally sound, in addition to presenting uncertainty regarding the duration of reserves in the world and frequent disagreements between producing and consuming countries (MOBINI et al., 2014). Renewable energy sources, in which biomass and its derivatives are utilized, have been highlighted because they present themselves as an alternative energy to fossil fuels. The in natura biomass, however, presents some drawbacks for its direct use in energy generation, including both low bulk density and calorific power and high moisture content. Processes such as pelletizing and torrefaction can be used to improve these undesirable characteristics, increasing their competitiveness against fossil fuels (WANG et al., 2013).

FLORESTA, Curitiba, PR, v. 48, n. 4, p. 493-502, out/dez. 2018

Magalhães. M. A. et.al.

ISSN eletrônico 1982-4688

DOI: $10.5380 /$ rf.v48i4.52766 
One of the main advantages of pelletizing is the increase in bulk density, allowing for transportation over longer distances. In addition, the pellets have a reduced size and constant shape that allows for the improved burning, handling processes in the industry, and presents lower moisture content, which increases the useful calorific power and, consequently, the energy production (KALIYAN; VANCE MOREY, 2009; SHAW et al., 2009). In addition, the torrefaction of the pellets also improves some of its properties, such as the increase in the calorific value and the reduction of hygroscopic equilibrium moisture, due to the degradation of less energetic and more hydrophilic compounds contained in the biomass (NHUCHHEN et al., 2014). All these upgrades favor the increase of energy density, thus making the biomass more attractive and usable as an energy source.

Torrefaction promotes changes in the chemical composition of the biomass, both at the level of structural components and elemental composition. The literature reports that the main effects of torrefaction are the reduction of hydrogen and oxygen content and the proportional increase of carbon, nitrogen, sulfur, and ashes to a greater or lesser degree (TUMULURU et al., 2011). These variations occur due to the elimination of the less thermally stable structural components, such as hemicelluloses and part of the cellulose, depending on the degree of torrefaction (CHEN; KUO, 2011). Lignin has a condensed structure, being rich in carbon-carbon bonds, which confer greater resistance to thermal degradation, whereas in its elemental composition, lower content of oxygen and hydrogen and higher carbon, nitrogen, and sulfur content is observed (PASANGULAPATI et al., 2012).

One of the ways to obtain torrefied pellets is post-pelletization torrefaction (GHIIASI et al., 2014). For this, the pellets must have high mechanical resistance to support the torrefaction process without disintegrating and generating fines, given that the equipment for this process keeps the biomass in constant movement.

The world market for pellets grew by an average of $14 \%$ per year since 2010, producing around 26 million tons in 2015. This year, Brazil had an installed capacity of 200 thousand tons per year, however, production was only 75 thousand tons. The low Brazilian production is a result of its small consumer market and difficulty in exporting the pellets, since the larger international markets follow norms with very strict quality standards (THRÄN et al., 2017). The numerous advantages of torrefied pellets can increase Brazil's participation in the international market, but it is necessary to determine the behavior of its chemical properties for widespread use, as well as to determine its biofuel potential in thermal energy generation. In this sense, the objective of this study was to evaluate the effect of torrefaction on pellets of Pinus sp. in terms of their chemical properties.

\section{MATERIALS AND METHODS}

The wood of Pinus sp., was turned into particles with a hammer mill and to then be used as the raw material. The particles were classified in overlapping sieves, collecting the fraction that passed through the $3 \mathrm{~mm}$ sieve and was retained in the $0.5 \mathrm{~mm}$ sieve.

\section{Production of the pellets}

The particles were dried in a forced circulation oven at $103 \pm 2{ }^{\circ} \mathrm{C}$ until reaching approximately $16 \%$ moisture content on a dry basis. The pellets were produced in a laboratory pelletizing press of the brand Amandus Kahl, model 14-175, with a capacity of $30 \mathrm{~kg} / \mathrm{h}$. The average pelletizing temperature varied around $106^{\circ} \mathrm{C}$.

\section{Torrefaction reactor}

For the torrefaction of the pellets, initially, they were dried to $0 \%$ moisture content to eliminate the influence of the water content on the treatments. Approximately $5 \mathrm{~kg}$ of pellets were used for each heat treatment. Three temperatures $\left(210,250\right.$, and $\left.290{ }^{\circ} \mathrm{C}\right)$ and three residence times $(10,20$, and 30 minutes $)$ were used in the torrefaction process, defined according to preliminary tests.

The torrefaction of the pellets was carried out in a screw type reactor developed at the Panels and Energy Laboratory of the Federal University of Viçosa, state of Minas Gerais, Brazil. The reactor consists of four basic components: pellet transport, heating, cooling, and gas exhaust systems (Figure 1). 


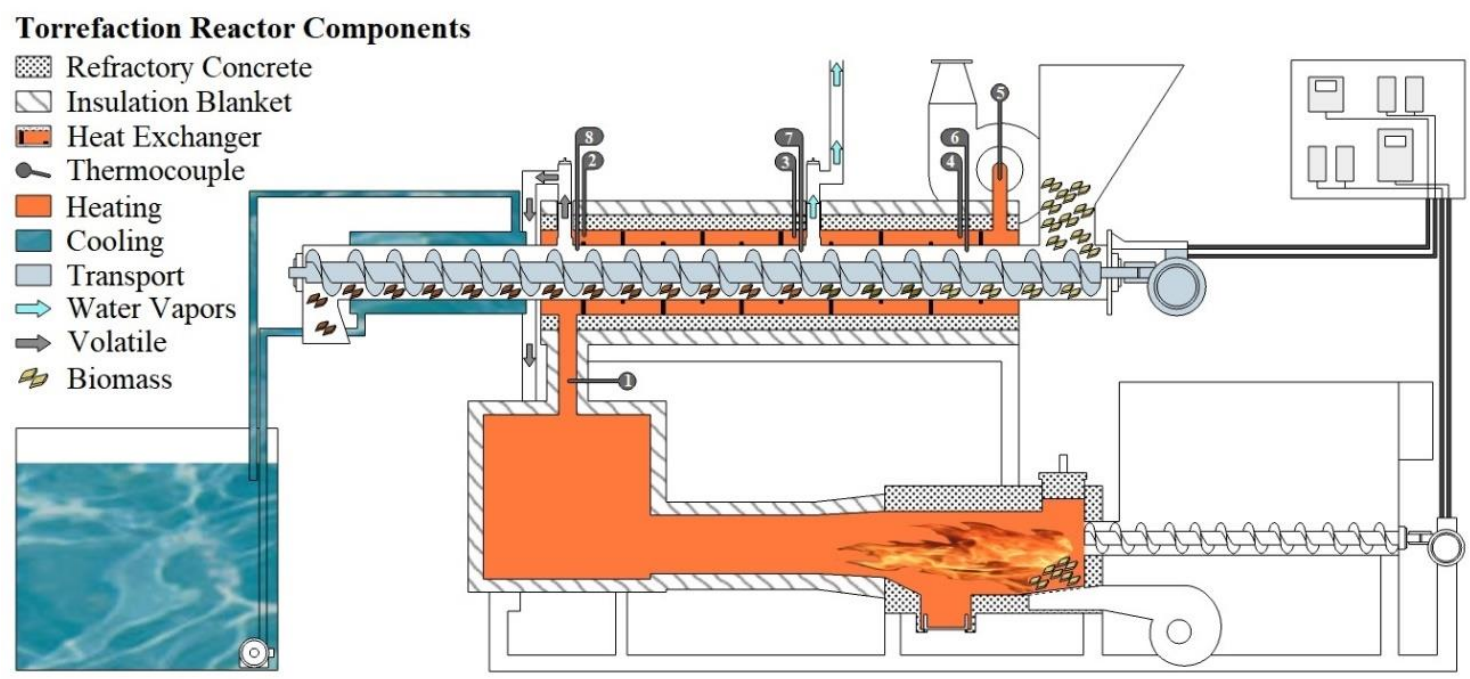

Figure 1. Schematic of the biomass torrefaction system. Required Patent - BR 1020160104840.

Figura 1. Esquema do sistema de torrefação de biomassa. Patente requerida - BR 1020160104840.

The transport system consists of an endless thread, driven by a gear motor, which pushes the biomass through a metal pipe of the feed silo, through the stages of heating and cooling, and then to the exit of the reactor.

The heating system consists of a pyrolytic biomass burner, which provides hot combustion gas to a "jacket" that lines the torrefaction section. The torrefaction occurs indirectly through the exchange of heat between the gas and the metal pipe.

The cooling system, located at the end of the heating step, is cooling the piping by means of indirect heat exchange with the water in constant circulation.

The exhaust gas system consists of two stages. The first refers to the removal of the heating gas from the pyrolytic burner with the aid of an electric exhaust fan, located at the end opposite the gas inlet. The second refers to the removal of the water vapors and volatile materials produced during the heat treatment. Exhaust is released by the "chimney" effect through two outlets located along the torrefaction section.

\section{Chemical Properties of Pellets}

For the thermogravimetric analysis, the samples were ground and classified between the overlapping sieves of 200 and 270 mesh. The wood thermal degradation study was performed using the equipment Shimadzu DTG-60, and the analyses were carried out in a nitrogen gas atmosphere with a constant flow rate of $50 \mathrm{~mL} / \mathrm{min}$. The thermograms were obtained starting at the temperature of $50{ }^{\circ} \mathrm{C}$ to the maximum temperature of $600{ }^{\circ} \mathrm{C}$ with a heating rate of $10^{\circ} \mathrm{C} / \mathrm{min}$.

The elemental composition (carbon, nitrogen, hydrogen) was determined according to the method 15104 (DIN, 2011a). The equipment used was the Vario Micro Cube CHNS, Elementar ${ }^{\circledR}$. The sulfur content was also determined using the elemental analyzer. The oxygen value was obtained by the sum of carbon, nitrogen, hydrogen, sulfur, and ash content, subtracted from 100, according to EN 15296 (DIN, 2011b).

The extractive content was determined in duplicate, according to TAPPI 204 om-88 (TAPPI, 1996), only substituting ethanol/benzene with ethanol/toluene. The insoluble lignin content was determined in duplicate by the Klason method (GOMIDE; DEMUNER, 1986). Soluble lignin was determined by spectrometry at the wavelengths of 215 and $280 \mathrm{~nm}$ (GOLDSCHIMID, 1971). The total lignin content was obtained by summing the values of soluble and insoluble lignin. The content of holocellulose (cellulose and hemicelluloses) was obtained by the sum of extractive contents, total lignin, and ash content, subtracted from 100. The immediate chemical composition of wood and pellets was determined according to ABNT NBR 8112 (ABNT, 1986) for determination of volatile materials, ash content, and fixed carbon content on a dry basis. 


\section{RESULTS}

\section{Thermogravimetric analysis (TG/DTG)}

In Figure 2, the thermogravimetric (TG) curves and the respective derivatives (DTG) are presented for the in natura and torrefied pellets at the temperatures of 210,250 , and $290{ }^{\circ} \mathrm{C}$ for 30 minutes in order to observe the effects of the torrefaction temperature.
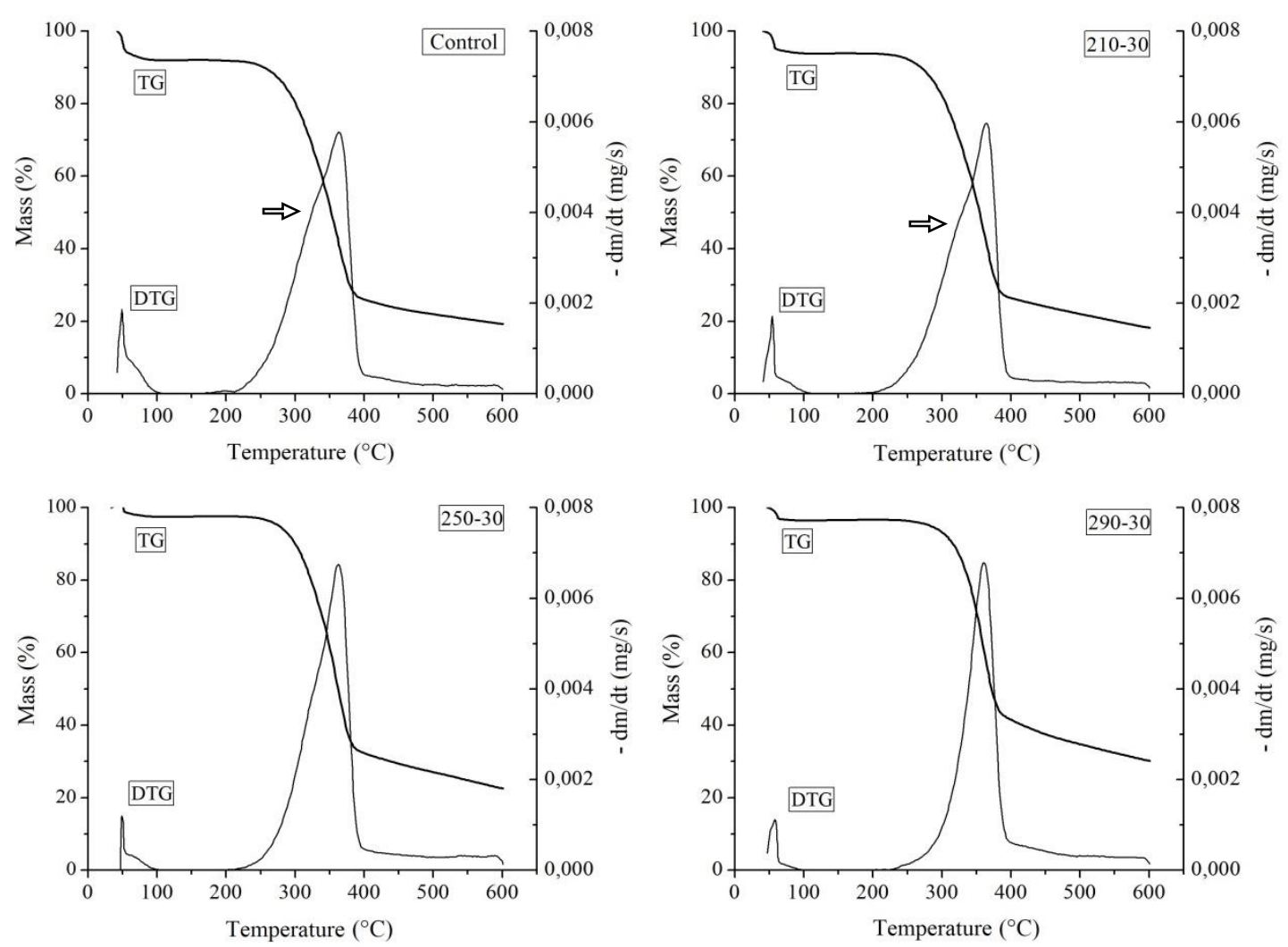

Figure 2. TG (mass) and DTG (-dm/dt) curves for the control and torrefied pellets at 210, 250, and $290{ }^{\circ} \mathrm{C}$ for the period of 30 minutes.

Figura 2. Curvas de TG (massa) e DTG (-dm/dt) para a testemunha e pellets torrificados a 210,250 e $290{ }^{\circ} \mathrm{C}$ no tempo de 30 minutos.

Table 1. Percent weight loss for the control and torrefied pellets according to the temperature ranges of thermogravimetric analysis.

Tabela 1. Perda de massa percentual para a testemunha e pellets torrificados em função das faixas de temperatura da análise termogravimétrica.

\begin{tabular}{cccccccccccccc}
\hline \multirow{2}{*}{ Treatment } & \multicolumn{10}{c}{ Temperature Ranges $\left({ }^{\circ} \mathbf{C}\right)$} \\
\cline { 2 - 11 } & $\mathbf{5 0 - 1 0 0}$ & $\mathbf{1 0 0 - 1 5 0}$ & $\mathbf{1 5 0 - 2 0 0}$ & $\mathbf{2 0 0 - 2 5 0}$ & $\mathbf{2 5 0 - 3 0 0}$ & $\mathbf{3 0 0 - 3 5 0}$ & $\mathbf{3 5 0 - 4 0 0}$ & $\mathbf{4 0 0 - 4 5 0}$ & $\mathbf{4 5 0 - 5 0 0}$ & $\mathbf{5 0 0 - 5 5 0}$ & $\mathbf{5 5 0 - 6 0 0}$ & RM \\
\hline Control & 5.07 & 0.00 & 0.17 & 1.47 & 9.66 & 27.92 & 26.81 & 2.47 & 1.59 & 1.37 & 1.32 & 19.29 \\
$210-30$ & 5.37 & 0.00 & 0.08 & 1.58 & 9.69 & 28.22 & 27.84 & 2.42 & 2.06 & 1.93 & 1.86 & 18.24 \\
$250-30$ & 3.22 & 0.00 & 0.00 & 0.57 & 6.76 & 28.04 & 29.87 & 2.89 & 2.42 & 2.22 & 2.25 & 22.60 \\
$290-30$ & 3.26 & 0.00 & 0.00 & 0.29 & 3.05 & 21.08 & 30.65 & 3.99 & 2.84 & 2.37 & 2.16 & 30.26 \\
\hline RM: residual mass at $600{ }^{\circ} \mathrm{C}$ & & & & & & & & & & & &
\end{tabular}

Figure 3 shows the thermogravimetric (TG) curves and the respective derivatives (DTG) for the pellets in natura and torrefied at $290^{\circ} \mathrm{C}$ for 10,20 , and 30 minute periods, thus being able to observe the effect of the torrefaction time. 

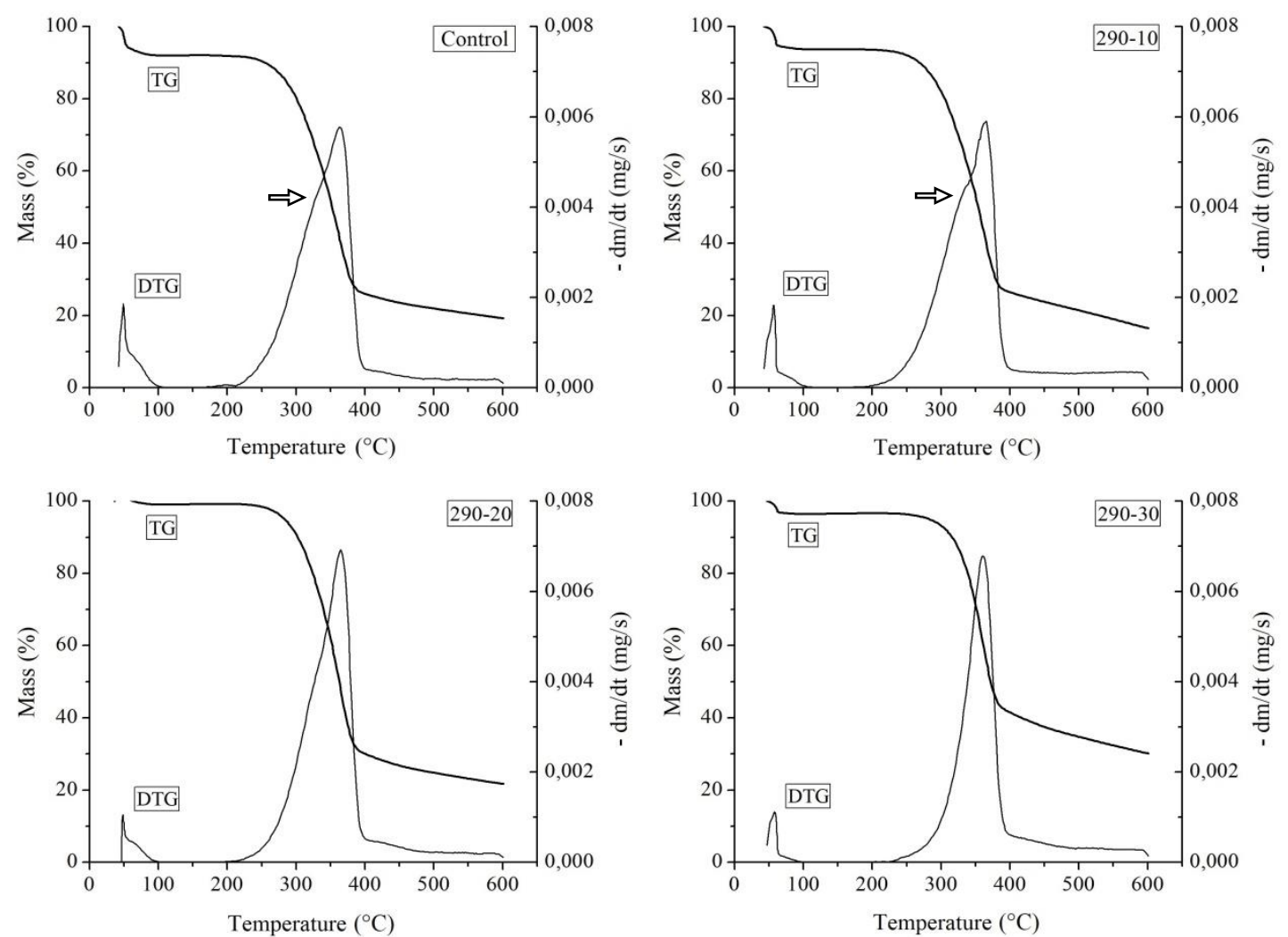

Figure 3. TG (mass) and DTG (-dm/dt) curves for the control and torrefied pellets at $290^{\circ} \mathrm{C}$ for 10,20 , and 30 minutes.

Figura 3. Curvas de TG (massa) e DTG (-dm/dt) para a testemunha e pellets torrificados a $290{ }^{\circ} \mathrm{C}$ nos tempos de 10,20 e 30 minutos.

Table 2. Percent weight loss for the control and torrefied pellets according to the temperature ranges of the thermogravimetric analysis.

Tabela 2. Perda de massa percentual para a testemunha e pellets torrificados em função das faixas de temperatura da análise termogravimétrica.

\begin{tabular}{cccccccccccccc}
\hline \multirow{2}{*}{ Treatment } & \multicolumn{10}{c}{ Temperature Ranges $\left({ }^{\circ} \mathbf{C}\right)$} \\
\cline { 2 - 11 } & $\mathbf{5 0 - 1 0 0}$ & $\mathbf{1 0 0 - 1 5 0}$ & $\mathbf{1 5 0 - 2 0 0}$ & $\mathbf{2 0 0 - 2 5 0}$ & $\mathbf{2 5 0 - 3 0 0}$ & $\mathbf{3 0 0 - 3 5 0}$ & $\mathbf{3 5 0 - 4 0 0}$ & $\mathbf{4 0 0 - 4 5 0}$ & $\mathbf{4 5 0 - 5 0 0}$ & $\mathbf{5 0 0 - 5 5 0}$ & $\mathbf{5 5 0 - 6 0 0}$ & RM \\
\hline Control & 5.07 & 0.00 & 0.17 & 1.47 & 9.66 & 27.92 & 26.81 & 2.47 & 1.59 & 1.37 & 1.32 & 19.29 \\
$290-10$ & 5.66 & 0.05 & 0.12 & 1.47 & 10.14 & 28.54 & 27.00 & 2.62 & 2.33 & 2.43 & 2.52 & 16.56 \\
$290-20$ & 3.31 & 0.00 & 0.00 & 0.80 & 7.21 & 28.27 & 32.79 & 3.36 & 1.96 & 1.63 & 1.46 & 21.77 \\
$290-30$ & 3.26 & 0.00 & 0.00 & 0.29 & 3.05 & 21.08 & 30.65 & 3.99 & 2.84 & 2.37 & 2.16 & 30.26 \\
\hline RM: residual mass at $600{ }^{\circ} \mathrm{C}$ & & & & & & & & & & & &
\end{tabular}

In Figures 2 and 3, lower initial mass loss for drying was observed for the treatments performed at $250{ }^{\circ} \mathrm{C}$ and 30 minutes, $290{ }^{\circ} \mathrm{C}$ and 20 minutes, and $290{ }^{\circ} \mathrm{C}$ and 30 minutes, indicating that the pellets in these conditions have lower moisture content.

For the control and treatments carried out at $210{ }^{\circ} \mathrm{C}$ and 30 minutes and $290{ }^{\circ} \mathrm{C}$ and 10 minutes, there is a mass loss region (indicated by the arrows) for the degradation of the hemicelluloses, which starts around $220^{\circ} \mathrm{C}$ and extends to $300{ }^{\circ} \mathrm{C}$, presenting a maximum mass loss rate around $270{ }^{\circ} \mathrm{C}$. In the other treatments at 250 and $290^{\circ} \mathrm{C}$, it is not possible to clearly observe this region in the DTG curve, since the heat treatment easily eliminates the hemicelluloses. The peak in the DTG curves is, in part, degradation of the cellulose, which has degradation

FLORESTA, Curitiba, PR, v. 48, n. 4, p. 493-502, out/dez. 2018

Magalhães. M. A. et.al.

ISSN eletrônico 1982-4688 
range between 300 and $380{ }^{\circ} \mathrm{C}$, presenting greater mass loss near $350{ }^{\circ} \mathrm{C}$. This peak tends to increase with respect to the increased torrefaction time or temperature, due to the increase in thermal stability of the biomass.

It can be seen in Tables 1 and 2 that the onset of the most pronounced mass loss for the control and for the treatments at $210{ }^{\circ} \mathrm{C}$ and 30 minutes and $290^{\circ} \mathrm{C}$ and 10 minutes occurs in the temperature range of 200 to $250{ }^{\circ} \mathrm{C}$, indicating the presence of hemicelluloses. In contrast, increasing torrefaction temperature or residence time slows the onset of mass loss to higher temperatures, showing that torrefaction increases the thermal stability of the biomass. The higher residual mass at $600^{\circ} \mathrm{C}$ corroborates the higher thermal stability of the pellets obtained in the treatments $250^{\circ} \mathrm{C}$ and 30 minutes, $290^{\circ} \mathrm{C}$ and 20 minutes, and $290^{\circ} \mathrm{C}$ and 30 minutes, while the latter presented the highest value.

\section{Elemental chemical composition}

Table 3. Contents of carbon, hydrogen, nitrogen, sulfur, oxygen, and ash.

Tabela 3. Teores de carbono, hidrogênio, nitrogênio, enxofre, oxigênio e cinzas.

\begin{tabular}{ccccccc}
\hline \multirow{2}{*}{ Treatment } & Carbon & Hydrogen & Nitrogen & Sulfur* & Oxygen & Ash \\
\cline { 2 - 7 } & $\boldsymbol{\%}$ & $\boldsymbol{\%}$ & $\boldsymbol{\%}$ & $\boldsymbol{\%}$ & $\boldsymbol{\%}$ & $\boldsymbol{\%}$ \\
\hline Control & 46.7 & 5.8 & 0.17 & 0.0 & 47.1 & 0.13 \\
\hline $210-10$ & 47.9 & 5.9 & 0.15 & 0.0 & 45.9 & 0.12 \\
$210-20$ & 47.3 & 5.9 & 0.17 & 0.0 & 46.5 & 0.13 \\
$210-30$ & 47.1 & 5.8 & 0.17 & 0.0 & 46.8 & 0.13 \\
\hline $250-10$ & 45.2 & 5.6 & 0.20 & 0.0 & 48.8 & 0.12 \\
$250-20$ & 49.3 & 6.1 & 0.16 & 0.0 & 44.3 & 0.12 \\
$250-30$ & 53.1 & 5.6 & 0.18 & 0.0 & 41.0 & 0.10 \\
\hline $290-10$ & 48.0 & 6.0 & 0.16 & 0.0 & 45.7 & 0.10 \\
$290-20$ & 52.0 & 6.2 & 0.18 & 0.0 & 41.5 & 0.13 \\
$290-30$ & 51.4 & 5.0 & 0.18 & 0.0 & 43.3 & 0.20 \\
\hline
\end{tabular}

* Not detected

Table 3 shows an increase in carbon content with increasing torrefaction temperature or time. Nitrogen increased in relation to the control, mainly from $250{ }^{\circ} \mathrm{C}$ upward. The hydrogen showed a tendency to increase until the 20-minute treatment with a reduction at 30 minutes, especially in the temperatures of 250 and $290{ }^{\circ} \mathrm{C}$. Oxygen reduced in relation to the control, as well as in the treatments at 250 and $290{ }^{\circ} \mathrm{C}$.

\section{Structural chemical composition}

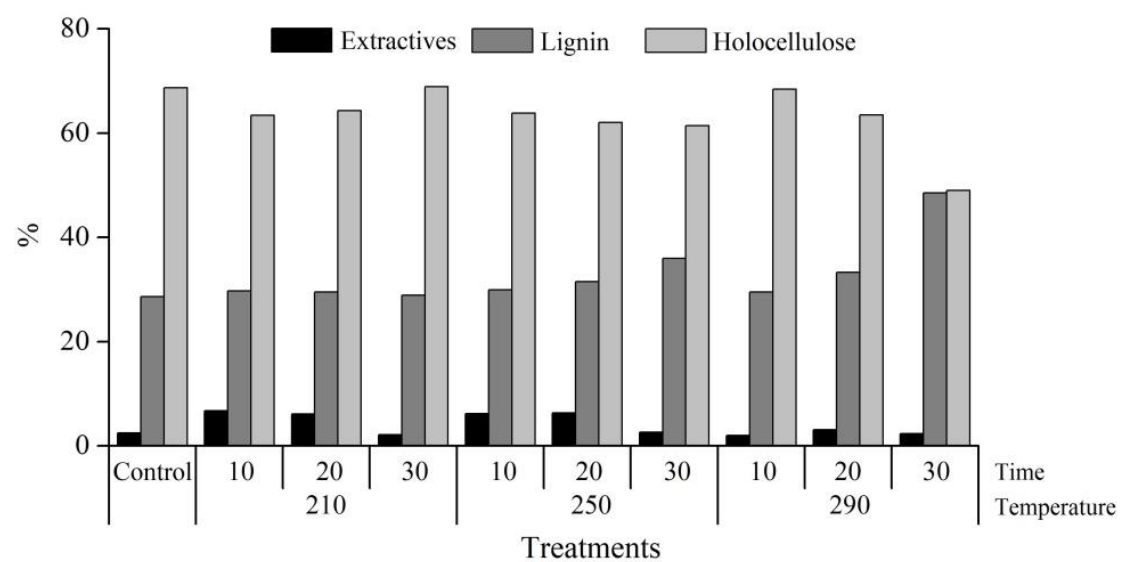

Figure 4. Extractive, lignin, and holocellulose contents for the treatments.

Figura 4. Teores de extrativos, lignina e holocelulose em função dos tratamentos.

In Figure 4, a general tendency of reduction can be observed in the content of holocellulose in the torrefied pellets, being more accentuated for the 250 and $290{ }^{\circ} \mathrm{C}$ treatments at the times of 20 and 30 minutes. As for the extractive content, there was a general tendency of increase with the increase of the time or temperature of torrefaction. Also, the lignin content increased proportionally with the reduction of holocellulose. 


\section{Immediate chemical composition}

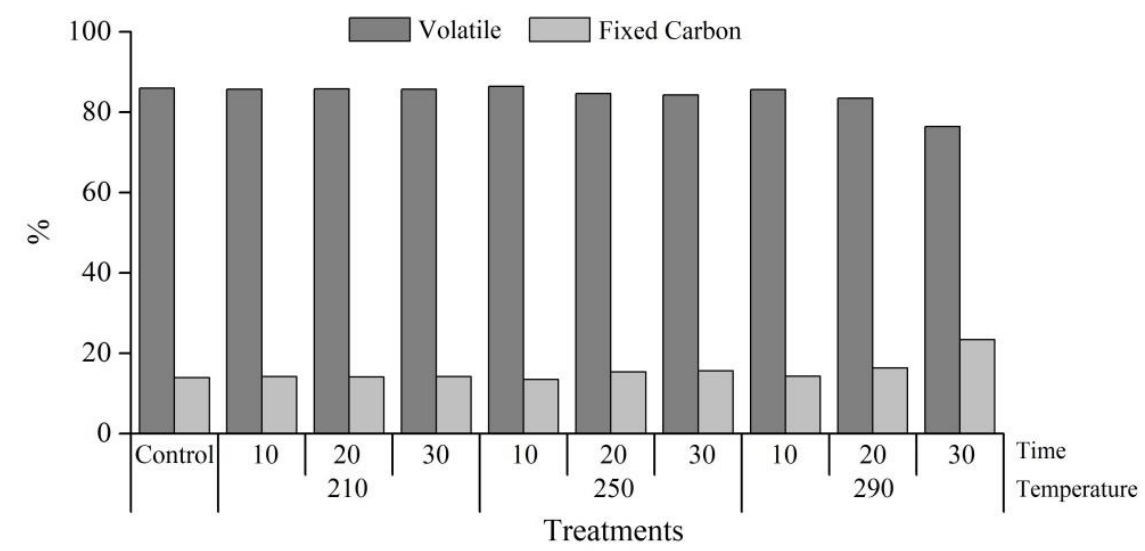

Figure 5. Contents of volatile and fixed carbon for the treatments.

Figura 5. Teores de materiais voláteis e carbono fixo em função dos tratamentos.

Fixed carbon showed a tendency to increase with increasing torrefaction time or temperature. The greatest increase was observed at the temperature of $290{ }^{\circ} \mathrm{C}$ for 30 minutes of torrefaction, corresponding to $67.9 \%$ in comparison with the control. The content of volatile materials decreased with the increase in residence time, especially at temperatures of 250 and $290{ }^{\circ} \mathrm{C}$, presenting a reduction of $11.1 \%$ in the latter when compared to the control (Figure 5).

\section{DISCUSSION}

One of the main effects of the heat treatment is the reduction of the hygroscopic equilibrium moisture content of the biomass. As a consequence, there is an increase in the useful calorific power and in the energy release at the moment of combustion (PENG et al., 2013).

With increasing torrefaction temperature or time, the thermal degradation range of the pellets becomes narrower and can be observed in the DTG curves (Figures 2 and 3). For the control, the degradation starts at about $220^{\circ} \mathrm{C}$, and for the most severe heat treatment $\left(290^{\circ} \mathrm{C}\right.$ and 30 minutes $)$, it starts near $240{ }^{\circ} \mathrm{C}$. The other treatments have initial degradation temperatures in between those mentioned. Regardless of the treatment, most of the thermal degradation of the pellets occurs at $380^{\circ} \mathrm{C}$, at which it is possible that the hemicelluloses and the cellulose have been completely degraded. Only part of the lignin in the biomass remains, which typically presents progressive degradation starting at low temperatures around $150{ }^{\circ} \mathrm{C}$ and extends to high temperatures. This characteristic can be attributed to the phenyl propane units that form strong bonds between them, giving rise to a condensed molecule with great resistance to thermal degradation (YANG et al., 2007; ZHOU et al., 2013).

In practice, a more thermally stable biomass promotes greater energy release at the moment of combustion because it has components with stronger chemical bonds, which release more energy when oxidized. The increase in the residual mass in the torrefied pellets occurs because the heat treatment eliminates less stable components, such as hemicelluloses, and preserves the higher molecular weight ones, such as lignin, which is rich in carbon. In addition, it promotes the proportional increase of the inorganic constituents.

The increase in the carbon content, with respect to the reduction in hydrogen and oxygen present in the biomass, can be explained by the proportional increase of the lignin as a function of eliminating the hemicelluloses and part of the cellulose. Lignin presents higher carbon content and lower content of both hydrogen and oxygen in its elemental composition. The opposite is observed for cellulose and hemicelluloses (PASANGULAPATI et al., 2012). The increase in the carbon content contributes positively to the generation of energy and can, therefore, be used as a parameter in the selection of biomass destined for combustion (REIS et al., 2012).

Hydrogen, even present in small amounts in wood, is one of the elements that contributes most to energy generation during combustion because it presents high calorific value (REIS et al., 2012). According to Nhuchhen et al. (2014), the increase in torrefaction time or temperature has a negative effect on the hydrogen

FLORESTA, Curitiba, PR, v. 48, n. 4, p. 493-502, out/dez. 2018

Magalhães. M. A. et.al.

ISSN eletrônico 1982-4688

DOI: $10.5380 /$ rf.v48i4.52766 
concentration because it eliminates part of the element in the form of volatile gases. Therefore, temperature control is important to keep part of the hydrogen in the residual mass.

Nitrogen has no significant effect on the higher calorific value of the pellets. However, contents of this element higher than $0.6 \%$ are undesirable during combustion, since nitrogenous compounds such as $\mathrm{NO}_{\mathrm{x}}, \mathrm{N}_{2} \mathrm{O}$, and $\mathrm{HCN}$ can form, which are harmful to the environment (OBERNBERGER et al., 2006; TUMULURU et al., 2011). Even with the occurrence of increased nitrogen content for some treatments, all obtained lower values than those mentioned by these authors.

The reduction in the oxygen content in the torrefied pellets, as observed at temperatures of 250 and $290{ }^{\circ} \mathrm{C}$ and times of 20 and 30 minutes, favors the use of this feedstock as a renewable fuel, since this element, unlike carbon and hydrogen, contributes in a negative way to energy generation. This is due to the reduction in the biomass higher calorific value (CARNEIRO et al., 2014; NHUCHHEN et al., 2014).

The ash content increased only in the treatments at $290{ }^{\circ} \mathrm{C}$ and times of 20 and 30 minutes (Table 3), but it did not affect the use of the pellets for energetic purposes. This increase is characteristic of the torrefied biomass, since the process occurs at low temperatures and, therefore, degrades only the organic components and preserves the inorganic components present in the wood (PHANPHANICH; MANI, 2011). It should be noted that high ash content, in addition to reducing the calorific value, is detrimental to the combustion processes because they cause fouling in the combustion chambers, corrosion of pipes and other equipment, and generation of residues (NHUCHHEN et al. 2014).

Cellulose has low or no contribution to reducing the amount of holocellulose, since its degradation starts at $300{ }^{\circ} \mathrm{C}$ (ZHOU et al., 2013). Therefore, the reduction observed is mainly due to the elimination of hemicelluloses. This results in significant improvements in the biomass quality because it decreases the hygroscopic equilibrium moisture, due to the loss of groups $(-\mathrm{OH})$ and, thus, reducing water adsorption sites in biomass (PHANPHANICH; MANI, 2011). Also, it is possible to emphasize the increase in the higher calorific value, since these components are less energetic when compared to the others, such as lignin, cellulose, and extractives that, for the most part, can remain in the torrefied material.

One possible explanation for the increase in extractives would be the formation of partially degraded products from the less thermally stable components of the wood. These products were removed by the solvents used in the analysis and, consequently, counted as extractives (BRITO et al., 2008).

The increase in the lignin content may result in an increase of the higher calorific value of the pellets. This is because it is a structural component with a greater amount of chemical bonds between elements (mainly carbon), which release large amounts of energy when oxidized. Furthermore, due to the structural arrangement of the lignin, it is hydrophobic. Thus, it exerts influence on the hygroscopic equilibrium moisture of the pellets and reduces this property as its proportion increases.

The reduction of the volatile material content for the torrefied pellets occurred due to the degradation of less thermally stable components, such as hemicelluloses. The degradation of some of these components forms gases composed basically of $\mathrm{CO}$ and $\mathrm{CO}_{2}$ (PARK et al., 2013). It should be noted that the volatile materials removed from the wood are rich in oxygen. Both the reduction of these volatile components and the increase in the fixed carbon content, which is more energetic carbon present in the wood, promotes the increase of the higher calorific value (PENG et al., 2013).

\section{CONCLUSIONS}

- The torrefaction of the pellets, mainly at the temperatures of 250 and $290^{\circ}$, promoted favorable modifications in the chemical properties. As a consequence, there was an increase in the higher calorific value and reduction of the hygroscopic equilibrium moisture, properties that have a positive effect on the energy density of the fuel.

- Torrefied pellets are a renewable fuel with favorable chemical characteristics for use in thermal energy generation or even for application in more noble conversion processes, such as gasification or pyrolysis for the production of bio-oil.

\section{ACKNOWLEDGEMENTS}

To CNPq, Fapemig, and Capes for the support provided to the development of this research. To the employee, Eder Cabral de Sousa, for the assistance in the construction of the torrefaction reactor. 


\section{REFERENCES}

ABNT - ASSOCIACAO BRASILEIRA DE NORMAS TÉCNICAS. NBR 8112: Análise química imediata do carvão vegetal. Rio de Janeiro,: 8 p. 1986.

BRITO, J. O.; SILVA, F. G.; LEÃO, M. M.; ALMEIDA, G. Chemical composition changes in eucalyptus and pinus woods submitted to heat treatment. Bioresource Technology, v. 99, n. 18, p. 8545-8548, 2008.

CARNEIRO, A. D. C. O.; CASTRO, A. F. N. M.; CASTRO, R. V. O.; SANTOS, R. C. D.; FERREIRA, L. P.; DAMÁSIO, R. A. P.; VITAL, B. R. Potencial energético da madeira de Eucalyptus sp. em função da idade e de diferentes materiais genéticos. Revista Árvore, v. 38, p. 375-381, 2014.

CHEN, W. H.; KUO, P. C. Torrefaction and co-torrefaction characterization of hemicellulose, cellulose and lignin as well as torrefaction of some basic constituents in biomass. Energy, v. 36, n. 2, p. 803-811, 2011.

DIN - DEUTSCHES INSTITUT FUR NORMUNG. EN 15104: Determination of total content of carbon, hydrogen and nitrogen - Instrumental methods. Berlim: CEN: 15 p. $2011 \mathrm{a}$.

EN 15296: Conversion of analytical results from one basis to another. Berlim: CEN: 15 p. $2011 \mathrm{~b}$.

GHIASI, B.; KUMAR, L.; FURUBAYASHI, T.; LIM, C. J.; BI, X.; KIM, C. S.; SOKHANSANJ, S. Densified biocoal from woodchips: Is it better to do torrefaction before or after densification? Applied Energy, v. 134, p. 133-142, 2014.

GOLDSCHIMID, O. Ultraviolet spectra. In: SARKANEN, K. V. e LUDWING, C. H. (Eds.). Lignins: ocurrence, formation, structure and reactions. 1 ed. New York: John Wiley Interprice, 1971. p. 241-266.

GOMIDE, J. L.; DEMUNER, B. J. Determinação do teor de lignina em material lenhoso: método Klason modificado. O Papel, v. 47, n. 8, 1986.

KALIYAN, N.; VANCE MOREY, R. Factors affecting strength and durability of densified biomass products. Biomass and Bioenergy, v. 33, n. 3, p. 337-359, 2009.

MOBINI, M.; MEYER, J.-C.; TRIPPE, F.; SOWLATI, T.; FRÖHLING, M.; SCHULTMANN, F. Assessing the integration of torrefaction into wood pellet production. Journal of Cleaner Production, v. 78, p. 216-225, 2014.

NHUCHHEN, D. R.; BASU, P.; ACHARYA, B. A Comprehensive Review on Biomass Torrefaction. International Journal of Renewable Energy \& Biofuels, v. 2014, p. 56, 2014.

OBERNBERGER, I.; BRUNNER, T.; BARNTHALER, G. Chemical properties of solid biofuels - significance and impact. Biomass and Bioenergy, v. 30, n. 11, 2006.

PARK, J.; MENG, J. J.; LIM, K. H.; ROJAS, O. J.; PARK, S. Transformation of lignocellulosic biomass during torrefaction. Journal of Analytical and Applied Pyrolysis, v. 100, p. 199-206, 2013.

PASANGULAPATI, V.; RAMACHANDRIYA, K. D.; KUMAR, A.; WILKINS, M. R.; JONES, C. L.; HUHNKE, R. L. Effects of cellulose, hemicellulose and lignin on thermochemical conversion characteristics of the selected biomass. Bioresource Technology, v. 114, p. 663-669, 2012.

PENG, J. H.; BI, X. T.; SOKHANSANJ, S.; LIM, C. J. Torrefaction and densification of different species of softwood residues. Fuel, v. 111, p. 411-421, 2013.

PHANPHANICH, M.; MANI, S. Impact of torrefaction on the grindability and fuel characteristics of forest biomass. Bioresource Technology, v. 102, n. 2, p. 1246-1253, 2011.

REIS, A. A. D.; PROTÁSIO, T. D. P.; MELO, I. C. N. A. D.; TRUGILHO, P. F.; CARNEIRO, A. D. C. O. Composição da madeira e do carvão vegetal de Eucalyptus urophylla em diferentes locais de plantio. Pesquisa Florestal Brasileira, v. 32, n. 71, 2012.

SHAW, M. D.; KARUNAKARAN, C.; TABIL, L. G. Physicochemical characteristics of densified untreated and steam exploded poplar wood and wheat straw grinds. Biosystems Engineering, v. 103, n. 2, p. 198-207, 2009.

TAPPI - TECHINICAL ASSOCIATION OF THE PULP AND PAPER INDUSTRY. TAPPI test methods T 204 om-88: solvent extractives of wood and pulp. Atlanta, USA. 1996.

FLORESTA, Curitiba, PR, v. 48, n. 4, p. 493-502, out/dez. 2018

Magalhães. M. A. et.al.

ISSN eletrônico 1982-4688

DOI: $10.5380 /$ rf.v48i4.52766 
THRÄN, D.; PEETZ, D.; SCHAUBACH, K. Global Wood Pellet Industry and Trade Study 2017. IEA Bioenergy, p.243. 2017.

TUMULURU, J. S.; WRIGHT, C. T.; HESS, J. R.; KENNEY, K. L. A review of biomass densification systems to develop uniform feedstock commodities for bioenergy application. Biofuels, Bioproducts and Biorefining, $\mathrm{v}$. 5, n. 6, p. 683-707, 2011.

WANG, C. W.; PENG, J. H.; LI, H.; BI, X. T. T.; LEGROS, R.; LIM, C. J.; SOKHANSANJ, S. Oxidative torrefaction of biomass residues and densification of torrefied sawdust to pellets. Bioresource Technology, v. 127, p. 318-325, 2013.

YANG, H. P.; YAN, R.; CHEN, H. P.; LEE, D. H.; ZHENG, C. G. Characteristics of hemicellulose, cellulose and lignin pyrolysis. Fuel, v. 86, n. 12-13, p. 1781-1788, 2007.

ZHOU, H.; LONG, Y.; MENG, A.; LI, Q.; ZHANG, Y. The pyrolysis simulation of five biomass species by hemicellulose, cellulose and lignin based on thermogravimetric curves. Thermochimica Acta, v. 566, p. 36-43, 2013. 